\title{
REMOVAL OF A GENERAL - THE REBIRTH OF A LATENT CONFLICT BETWEEN TWO SOVEREIGN STATES: USA AND IRAN
}

\author{
Diana CHIȘ-MANOLACHE \\ "Carol I" National Defense University, Bucharest, Romania \\ dianamanolache88@yahoo.com \\ Ciprian CHIȘ \\ "Carol I" National Defense University, Bucharest, Romania \\ chis.ciprian@yahoo.com
}

\begin{abstract}
Generally speaking, the relations between different states of the world, but especially between the states that represent world powers or have a certain type of arsenal, are able to influence the stability and the state of calmness from a certain region of the world, but also the notion of peace at the globally level. The 2020 year began with such a situation, in the sense that United States of America and Iran, which have been for a long period in relations not among the most well, have arrived at a moment that could represent, to a very large extent, the starting point of a conflict that will enter in the world history. The elimination of a very important Iranian general by US troops in early January 2020, by a surprise attack amonk Iraqian teritory, markedly aggravated relations between the United States of America and Iran, but also between the great world power and Iraq or other major global players who have harshly criticized the US attack.
\end{abstract}

KEYWORDS: Iranian general, security, agression, drones, ciber attack

\section{Introduction}

The two states that have been for a long time in the relations, not one of the best, rather tense than peaceful, seem to have reached in 2020, again, at a point that could lead, with a veru high probability, to the development of some atypical conflicts or crises in the Middle East area.

The killing of Qasem Soleimani, a very well-known iranian general, result of a drone attack developed by US troops in early January 2020, an attack that took place in Iraq (noting that the attack did not take place in the territory of the Iranian state), has aggravated, in a visible way the tensions between the United States of America (hereinafter referred to as the USA) and Iran, which anyway were not the best, but also, in the same time, between the USA and Iraq. Obviously, the reverberations of this attack had an impact on the whole world, the positions of the other great powers, but also of other states being among the most diverse.

This event occurred on the backdrop of Tehran's opportunistic and pragmatic foreign policy, a policy that has not always respected the demands of world alliances or 
of stronger nations, no matter what they are, especially when it comes to Afghanistan, where General Soleimani has played a critical role. At the same time, we must also point out that, as the head of the Quds Force, about which we will discuss later, General Soleimani was also the key architect of Syrian President Bashar al-Assad's brutal attacks on anti-protesters and anti- governmental rebels in the war that took place some years ago (about nine years ago).

\section{Historical Parallelism - Back Bow Over Time}

Inevitably, the killing of General Soleimani had as a consequence the appearance of more fears about the possibility of starting a major armed conflict, fears which, thus, we consider to have been and are still justified. Moreover, more many pessimistic voices in the public space have declared in the media (both written and televised) that the killing of General Soleimani could be the beginning of World War III. Therefore, the assassination of Iranian general Qasem Soleimani is compared to the murder of the Austro-Hungarian archduke Franz Ferdinand, who took place in Sarajevo in 1914, an event that triggered the First World War.

Regarding the assassination of Archduke Franz Ferdinand on June 28, 1914, we must remember that, after the attack (also known as "the shot that was heard around the world") (The attempt from Sarajevo), both the Archduke and his wife, the Duchess Sophie Albina Chotek, lost their lives. Following the investigation of that time, it was found that the killer was a Serbian extremist by the name of Gavrilo Princip, one of the six members of a terrorist network coordinated by Danilo Ilić, who had behind the Black Hands panslavist organization, but also the secret group "Mlada Bosna" or Young Bosnia (Danilo Ilić - the biography). The main actors from shadow (or the back characters pf this attempt), who conspired this attack were: the colonel Dragutin Dimitrijević, the head of the Serbian Military Information Service, the major Vojislav Tankosić, his right hand and the spy named Rade Malobabić. The major Tankosić was the one who armed the assassins with bombs and pistols, later training them in order to complete the proposed plan.

The political objective of the attempt from Sarajevo was the separation of the southern Slavic provinces from the southern of Austro-Hungary Empire, so as to form the Great Yugoslavia. This event (the attempt from Sarajevo) led directly to the outbreak of World War I, given the fact that Austro-Hungary sent an ultimatum to Serbia, which was, however, partially rejected. This Serbian rejection determined Austro-Hungary to submit a declaration of war, that was equivalent, at that time, with the outbreak of the first global conflagration.

If we analyze, comparatively, the two events, we could affirm that we are not in a position to draw a parallel between them or to say that these events are similar, especially since they occurred over 100 years and that both had other motivations underlying their development. However, it is obvious that both events had and, consequently, could have (in the present described situation - Iran versus USA), the escalations of the relations within international political plan, with very serious consequences for the whole of humanity.

In the current context, produced by the killing of the Iranian general Soleimani, we consider that it is more important to make an analysis regarding the possibility or chances of a conflict between the USA and Iran, at a global level, and also an analysis regarding the military power of the armed forces of the two states.

This analysis must start from the strategic purpose of Tehran both in the disposal area and worldwide. According to 
Tehran's policy over the past few years, this goal is to project its influence and to defend its interests in the Middle East or, at least, not to allow strong rivals in the area, such as Saudi Arabia and Israel, declared USA allies, to achieve the superiority in the region. We must also mention that Tehran has no friends among the major players in the region, but according to the diplomatic and political relations, developed in recent years, it is assumed that Iran would have quite good relations with Russia and China, but does not really have faithful allies among the great powers, which cannot be said about the USA.

Until the time of the lethal attack led by USA troops against the Iranian general Soleimani, earlier this year, the Iranian state, through different ways or in various forms, has harassed USA troops installed in the countries from Middle-East region, with the aim of determining them to reduce the activity and even to permanently withdraw from this region. Thus, being a country quite isolated in terms of alliances, Iran chose to exploit the vulnerabilities of USA troops and its allies through interposed, but also to resort to asymmetrical attacks.

Regarding the power ratio between the two states, we apreciate that it is no longer necessary to mention that the Persian army is inferior to the American one, having allocated to the defense a rather modest budget, which would result in the impossibility of conducting a direct and opened conflict with the American forces and, implicitly, with other US allies from the vicinity and beyond. Thus, everyone is of the opinion that, as far as possible, Iran will avoid an opened conflict with the USA and will prefer proxy conflicts, through interposed or atypical conflicts.

As well as we know, Iran's nuclear program has been and still is very controversial, but at present, this state has not the capacity to produce atomic weapons which to use as a potential threat in the battle with rivals in the area and beyond.
Also, Iran has not ballistic missiles that have a sufficiently large range of action to threaten USA territory.

According to statistics, the Persian army is the eighth largest in the world, which is why the leaders of this state (both political and military leaders) considered the best strategy to fight with a much stronger state (such as the USA) is given by atypical attacks and by harassment of any form.

Thus, according to a study realized by the International Institute for Peace Research from Stockholm, in 2018 Iran had a budget allocated for defense of $\$ 13.2$ billion, thus representing the 18th largest budget allocated to defense in the world (Tian, Fleurant, Kuimova, Wezeman \& Wezeman, 2018), ranking, from this point of view, very far from the USA (with a budget of $\$ 649$ billion allocated for the defense), as well as under the most significant traditional regional rivals, as: Israel (the 17th defense budget in the world with a defense budget of about $\$ 16$ billion) and Saudi Arabia (the 3rd in the world with a defense budget of about 68 billion of dollars).

Also, to highlight the power ratio between USA and Iran, but also between Iran and USA allies in the region, it is important to emphasize that between 2009 and 2018, Tehran bought only $3.5 \%$ of what Saudi Arabia bought to develop its army.

Therefore, it is obvious that the USA, through the budget allocated for defense, is, if we could say so, in light years away from Iran.

Moreover, under the economic impact of imposing of some sanctions on the part of the USA, it is obvious the fact that Tehran's budget will steadily shrink in the coming years, including that allocated to the military sector.

In another statistic, carried out by 2020 by Global Firepower and Business Insider, in a ranking of the armies of the countries of the Middle East, the Iranian 
army was placed the 3rd from 15 countries evaluated in this area (Middle East Military Strength, 2020).

In this ranking of the military powers in the Middle East, Egypt and Turkey (eternal rival states of Iran from that region, with which Iran brings a permanent competition on all dimensions), are ranked ahead of Iran, that means a lot of things. According to the same statistics, in the world ranking, in 2020, the Iranian army would be ranked the 14th out of 138 countries that there were evaluated, having a number of 523,000 active soldiers (the 8th army in the world army ranking from this point of view), and 350,000 reservists (the 17th army worldwide considering this indicator).

It is obvious that in this ranking, the USA ranks the first, for which any comparison between the two mondial powers is almost useless, in fact we appreciate that it is almost insignificant.

However, we will list, briefly, just for information or to highlight the differences, some of the combat capabilities existing in the endowment of the two nations, thus underlining the fact that, at present, Iran is not able to start a direct conflict with the USA, resulting so that a direct confrontation between the two states is almost impossible.

Thus, overlooking the fact that the number of USA enlisted personnel is at least 2.5 times bigger than that of Iran, we mention that the USA has over 13,000 aircraft (combat, attack, transport, training, helicopters, etc.), 26 times more than those of Iran, which has a total of 510 aircrafts.

To further highlight the inferiority of the capabilities belonging to Iranian Air Forces in comparison with USA Air Force capabilities, we must note that some iranian aircrafts are still endowed during the 1991 Persian Gulf war, when Saddam Hussein (then president of Irak from that time) moved a part of the aircrafts from Kuwait to Iran in order to avoid to be destroyed by Americans troops.
It should be noted that the majority of aircrafts from the endowmnent of Iran's air force is represented by American production aircraft F-4, F-5 and F-14, assembled in the 1970s, called "Tizparvazan" (Flying Jets) by Iranians. Following the 2015 nuclear agreement, which eliminated international sanctions against Iran, and which invigorated the Persian economy, Iran had the opportunity to renew its military air fleet. One of the options was the French model Mirage 2000, but Tehran preferred the more familiar models, i.e. the American and Russian ones. However, Iran rejected Russia's offer, which was ready to sell 30 modern Suhoi30 aircrafts. The reason for refusing to purchase this type of fighter plane would have been the reluctance of the Islamic Revolutionary Guard Corps, whose leaders did not want that the ordinary army to become too strong.

It is important to mention the number of tanks (a fairly important combative force in a direct land conflict), with the USA having about 6,300 tanks, almost 3 times more than Iran having a number of about 2060 tanks. Here we should point out that most Iranian tanks are outdated models, some of them even out of a very good functioning, with the exception of the Karrar model, which came into the Persian Army's equipment in 2018. There have been a lot of discussions around the endowment of the Iranian army for this tank, having in mind the significant similarity with the Russian T-90 tank, but Tehran has denied and continues to deny the information or assumptions that it would have been collaborating with the Russians in producing this model.

Taking ino the account the above comparisons, regarding the military power of the two states, we could only develop timid discussions about a report of forces that should worth be considered. If we talk about the maritime fleets of the two states, we could firmly affirm the fact that Iran 
does not even impress, because as of some endowment statistics, Iran has not any aircraft carriers or destroyers, only 3 corvettes, 7 frigates and other ships that are insignificant in terms of firepower, compared to the USA that has 20 aircraft carriers, 91 destroyers and many other warships, which says everything in case in which, during a possible conflict between the two states, some of these military capacities of combat would be involved.

However, it should be noted that among the submarines that Iran has in endowment, it also holds the Russian model known in the West as "kilo" or "paltus" (Kilo-class submarine), halibut in Russian language, nicknamed by connoisseurs as "black hole" because it is unheard of. The Kilo class is a class of diesel-electric attack submarines designed and built in the Soviet Union for the Soviet Navy. It was produced until the mid-1990s, when its production was replaced by a more advanced version.

For a brief comparison of the armed forces of the two states, a comparative tabular representation of the most important combat technique in their endowment, reveals, in an obvious way, the USA clearly favorable balance of power, which say a lot about the imminence of a conflict between these states and their allies.

\begin{tabular}{|c|c|c|c|}
\hline $\begin{array}{l}\text { The Armed Force The state } \\
\text { Category/The Combat Tehnique }\end{array}$ & IRAN & USA & $\begin{array}{c}\text { The power/ } \\
\text { forces ratio } \\
\text { (Iran vs USA) }\end{array}$ \\
\hline \multicolumn{4}{|l|}{ Airpower } \\
\hline Fighters & 155 & 2.085 & $\sim 7,5$ la 100 \\
\hline Transports & 62 & 945 & $\sim 6,6$ la 100 \\
\hline Dedicated attack & 23 & 715 & $\sim 3,2$ la 100 \\
\hline Trainers & 94 & 2.643 & $\sim 3,6$ la 100 \\
\hline Special-missions $^{*}$ & 9 & 742 & $\sim 1,2$ la 100 \\
\hline Helicopters & 100 & 5.768 & $\sim 1,7$ la 100 \\
\hline Attack Helicopters & 12 & 967 & $\sim 1,2$ la 100 \\
\hline Serviceable Airports & 319 & 13.513 & $\sim 2,4$ la 100 \\
\hline Land Forces & IRAN & USA & The ratio \\
\hline Tanks & 2.056 & 6.289 & $\sim 33$ la 100 \\
\hline Armored Vehicles & 4.300 & 39.253 & $\sim 11$ la 100 \\
\hline Self-Propelled Artillery & 570 & 1.465 & $\sim 39$ la 100 \\
\hline Towed Artillery & 2.088 & 2.740 & $\sim 76$ la 100 \\
\hline Rocket Projectors & 1.935 & 1.366 & $\sim 1,4$ la 1 \\
\hline Naval Forces & IRAN & USA & The ratio \\
\hline Aircraft Carriers & 0 & 20 & incomparably \\
\hline Destroyers & 0 & 91 & incomparably \\
\hline Frigates & 7 & 0 & Incomparably \\
\hline Corvettes & 3 & 19 & $\sim 1$ la 6 \\
\hline Submarines & 34 & 66 & $\sim 1$ la 2 \\
\hline Patrol Vessels & 342 & 13 & $\sim 26$ la 1 \\
\hline Mine Warfare & 8 & 11 & $\sim 1$ la 1 \\
\hline
\end{tabular}

* - These aircrafts represent air platforms specifically designed or developed to achieve an over-battlefield role by utilization of advanced onboard equipment or specialized trait. We could name or include here: Airborne Early Warning (AEW), Maritime Patrol Aircraft (MPA), and Electronic Warfare (EW) platforms. 
In order to carry out a complete analysis of the military picture corresponding to the two states, it is necessary to approach some qualitative nuances strictly related to them.

In this sense, Tehran is a quite important enemy, a military actor that is more difficult to approach and defeat, compared to Iraq or Afghanistan, the oldest USA enemies in this region. Iran is a country with a large population, over $80,000,000$ inhabitants, spread over about $1,648,000 \mathrm{~km}^{2}$, aspects that can hinder a possible invasion or an absolute control exercised by the USA. Moreover, the rather rugged terrain, specific to this area, is not conducive to a direct land invasion, being rather conducive to guerrilla warfare.

Over time, Iran has used both conventional and unconventional capabilities in order to achieve intern and international goals. In an attempt to strengthen its influence in the region, Iran is constantly trying to maintain its ties and links with the international community, and at the same time to develop its own military capabilities in order to achieve an effective defense.

Although an enemy as advanced and well-endowed as the USA is extremely difficult to defeat, even by major global military actors, in order to gain some advantage in a possible direct conflict, Tehran's leaders focus on three extremely important elements: internally developing of ballistic missiles, that are able to destroy targets or objectives throughout the region, the handling of the Strait of Hormuz by the use of some combat technique from the endowment of coastal naval forces, in the sense of hindering or pirating oil transports (vessels or ships), and the support for those who are willing to carry out unconventional operations.

Also, in recent years, Iran has begun to take steps to improve both its defensive and offensive capabilities. Moreover, Iran has begun to review its military doctrines, to make changes in the way of how training is conducted, and to develop its defense tactics and force structures.

As mentioned before, issues such as: the improving of air defense, the developing of own missile programs or the increasing of naval forces combat capabilities, will be strengthened by the development of areas specific to the conduct of electronic warfare and air defense.

Therefore, Iran's conventional forces are in a continuous process of development and operationalization, a process that has great chances to materialize, especially from October 2020 when the military embargo imposed by UNO, by Resolution No. 2231, will expire, and Iran will be able acquire modern military capabilities.

As a general conclusion about the power ratio between the two states, it is clear that Iran is not a remarkable global power or a force that could pose real problems to USA in the event of a direct armed conflict. For this fact, Iran will certainly adopt a careful, well-paid tactic in its relationship with the USA, and the attacks or actions that will develop will be characterized by atypia and asymmetry. Most likely that, in the first phase, Iran will resort to, trying to give lightly strikes at various USA government sites or to realize cyber-attacks to different sites belonging to this state.

However, following this quantitative analysis of the forces at the disposal of the two states and from which we conclude that the USA is at a clear advantage over Iran, it is necessary, in order to carry out a complete analysis, to discuss, in short terms, however, about the aspect related to the place of a possible confrontation between the two powers. Thus, will a possible war between the two states take place in Iran, on the territory of this state or in its vicinity? How will the USA act in order to achieve a certain success and what kind of forces will it project in this area to obtain a favorable result? In fact, no matter 
how many questions are asked about a conflict between the two states (both of them are sustained in one form or another by various other states), the USA has a clear advantage, but it is normal to exemplify a few hypotheses in this regard.

Thus, it is more than certain that the USA and its allies will not act as in the case of the 1991 Gulf War against Iraq or as in 2003 when they invaded Iraq, in what represented the Operation called "The liberation of Iraq by the United States of America" (before March 19th, 2003, it was called Operation "Enduring Freedom", a continuation of the war in Afghanistan). Here, we must consider both the difference between the two states (Iran and Iraq) and the time factor, in the sense that everything related to 2020 and we refer here especially to the military technology and current combat capabilities, differ in a very large measure of the military technology specific to year 1991 or year 2001 .

First of all, we must point out that Iran in 2020 is much stronger, better structured and better endowed than Iraq in 1991 or in 2003. In addition, in terms of population, Iran has a larger population than Iraq, of about three times, and this aspect made that Iran to be considered an important military power. Also, this aspect and the way in which the military power of Iran is organized will certainly prevent the USA from deploying or disarming paratroopers on the territory of this state, in order to launch direct actions.

For the protection of their own troops, but also of those of the allies that will indisputably enter into this possible armed conflict, the ground attacks or a direct invasion will be avoided initially, more than likely. Thus, for the begining, the USA and its allies will adopt medium-range ballistic missile strike tactics. The destructive actions of these missiles will be followed, more than likely, by the rapid conduct of air raids with last generation dedicated attack aircraft and bombing aircraft.
It should be noted that, due to the significant number of soldiers stationed in the territory of several states in the area, quite important USA allies, all ballistic missile attacks, respectively all take-offs and landings of attack aircraft and bombers will take place on the territories of these states. Among these states, we must mention: United Arab Emirates, Saudi Arabia, Qatar, Kuwait or Oman. Also, it is possible that, in order to be able to break as many flanks of Iran's air defense as possible, the USA and its allies will conduct simultaneous missile fires from the territories of all allies in the area, which could raise serious problems for the level of Iran's effective air defense.

Another possible scenario, but probably more difficult, more costly and subject to broader international law, would be for the USA and its allies to deploy more maritime combat capabilities in the Strait of Hormuz, given their mixed combat capacities (see aircraft carriers, destroyers or submarines), as well as the totally unfavorable balance of forces for Iran. Iran's naval forces are far below the USA naval forces, not to mention other USA allies, and the development of a naval conflict will certainly lead to the defeat of the Iranian state. Thus, it is clear that the implementation of this course of action, supported by ground-based missile attacks developed from the territories of all USA allied states in the area, is very favorable to the USA and its allies and could have a real chance of success in a relatively short period of time.

But, in both scenarios briefly described in the previous few paragraphs, we did not consider a possible involvement of the Chinese state in this possible conflict, in the sense of supporting Iran.

We must remember that the Chinese state is a supporter of the Iranian state (perhaps not the most fervent, but an extremely important one), and a possible involvement of China in such a conflict 
would be possible given that the USA is the number one competitor of China both militarily and economically. It is obvious that China's involvement in such a conflict would radically change the data of this discussion, but the development of this topic may be the subject of a further debate, which may constitute a much broader work than this article, as many and diverse issues can be considered.

\section{Iranian Rockets - The Strength Capacity of the Iranian Army}

Given that sanctions imposed on Iran by the USA and not only by the USA, have drastically reduced oil exports and hit the economy of Iran, we affirm that imports of various goods, including imports of military products, have decreased significantly.

As a result, the Persian army was forced to rely on local development of new technologies and on cheaper equipment imported from Russia and China. To make up for the gap between the US and its regional rivals, Iran has focused on building a short-and medium-range ballistic missile system, which is recognized as the most developed in the region. Thus, Iran created the Shahab 1 rocket which has a range of $300 \mathrm{~km}$. Instead, in response to the possibility of using this type of missile, Washington installed several missile shields in some neighboring countries (USA allies), in order to prevent potential ballistic threats from Iran.

It is important to highlight that Iran has the largest inventory of ballistic missiles in the Middle East and is developing indigenous weapon systems such as long-range missiles.

We must also point out that the Iranians developed a rocket with an action range of $2000 \mathrm{~km}$, namely Shahab 3. Given this range, it is clear that Iran has become a real threat to Israel, as the latter could be hit by such a missile. This would be Tehran's last resort weapon. Iran also has in endowment 32 Russian S-300 ground-to-air missile systems that are quite efficient. More than this information, we have to say that Iran possesses some missiles included in Sejil-series that are ballistic surface-tosurface missiles. Sejil missiles represent a family of Iranian solid-fueled medium range ballistic missiles. Sejil missiles are replacements for the Shahab liquid-fueled ballistic missiles. The missile profile of the Sejil closely matches those of the Ashura (or Ghadr-110, another iranian missile).

Uzi Rubin, the founder of Israel's missile defense program, assesses Iran will gradually replace its liquid-propelled Shahab missiles with solid-fuelled Sejil-2 to improve the survivability and agility of their strategic missile forces.

Sejil missiles are covering the entire area of Israel, Saudi-Arabia, Egypt, Turkey and Pakistan, from launch positions in central Iran. Rubin estimates that Iran will be able to extend its missile strike capability to $3,000 \mathrm{~km}$, with strike capability reaching well into central Europe.

The Persian Army also developed some intercontinental missiles, but their development was suspended after the 2015 nuclear agreement, given that this type of missile was designed to carry nuclear cargo.

After the USA withdrew from the nuclear treaty in 2018, Iran gradually began to dismantle all its commitments, and the killing of general Soleimani is believed to have led Tehran to give up entirely within the limits imposed by the nuclear treaty that was totally ignored or even "dead" we could tell. In this context, it follows that Iran could resume, at any time, the program of development of intercontinental missiles that have the capacity to transport nuclear cargoes.

\section{Drones and Cyber Attacks}

Last but not least, Iran has a complete set of drones, which it has used in operations in Iraq and Israel. It is believed that all Iranian drones were also used in the attack on oil installations in Saudi Arabia 
that caused significant damage to the Saudi government.

The Iranian Revolutionary Guards also have a division specialized in cyber attacks, which has carried out such attacks on and off the borders of Iran. After Soleimani's assassination, several cyber security experts in the world's great powers said that one of Tehran's possible responses would be a cyber-attack against USA entities (Iran's military response may be 'Concluded' but cyberwarfare threat grows). Lastly, Iran has a complete drone liner, which it has used in operations in Iraq and Israel. It is believed that all Iranian drones were also used in the attack on oil installations in Saudi Arabia that caused significant damage to the Saudi government.

After the killing of Major-General Qassim Soleimani, also having in mind the endowment technique that could be used for developing a direct conflict with the USA, it is more than likely that Iran will adopt a fight focused mainly on the use of informatics systems, which will be focused on the boycott of the informatics systems of some USA institutions, including, most likely, the USA military informatic systems.

This way of action of the Iranian army is more than likely considering Iran's history of cyber-attacking both the USA and its allies. Thus, it was found that in the days following the assassination of Iranian General Soleimani, Iranian hackers (or the pro-Iranians ones) attacked USA governmental sites and conducted several divisive misinformation campaigns on social media. As an example, it could be seen that members of the cyber base in Miqdad (Iran) used some official channels of the state through which they sent various threatening messages with attacks or reprisals on the USA and Israel.

These threats also materialized in the days following the event that took place in early January 2020 . Thus, the cybersecurity company CrowdStrike (a cyber security technology development company based in Sunnyvale, California, that provides security services, information about threats and responses to cyberattack) warned customers that it was noticed that hackers who support the Islamic Revolutionary Guard Corps from Iran attack local sites belonging to various institutions in the cities of Minneapolis and Tulsa in Oklahoma, with images that honored the Iranian general Soleimani.

Moreover, Iranian or pro-Iranian hackers alleged that they are associated with Iran in terms of an attack on the official website of the Federal Library Depository Program, a sub-branch of the Government Publishing Office, in the sense in which that was posted a picture with the bloodied face of USA President Donald Trump, as a result of somebody punching him.

In the same context, of threats and attacks in the cyber environment, an adviser of the President of Iran, Hassan Rouhani, used the Twitter platform to post some messages on the websites of US President Trump's properties, stating: "Our only problem is Trump. In the event of a war, he who will be the one who bears the entire responsibility" (Iran's military response may be 'Concluded' but cyberwarfare threat grows).

\section{Islamic Revolution Guards Corps - an Army in an Army}

Given the fact that in the previous pages we have discussed the phrase of the Iranian Islamic Revolutionary Guards Corps (IRGC - hereinafter), we will present below some data on this military component of the Iranian state.

Thus, of the 523,000 active soldiers of the Iranian army, at least 150,000 belong to the IRGC. This military component represents one of the strongest components of the Iranian army. The IRGC commander is usually a general who is directly subordinate to the supreme Iranian leader, nowadays Ayatollah Ali Khamenei. 
We must specify that the Iranian forces, especially IRGC, do not depend solely on state budget financing, they controlling some of the total value of companies listed on the Tehran Stock Exchange and owning thousands of other companies that bring in revenue for the army. Several international voices claim that IRGC controls a large part of the underground economy in the state.

IRGC is a branch of the Iranian Armed Forces, so named because it was founded after the Iranian Revolution from April 22, 1979, along with the establishment of the Islamic Republic of Iran, by the order of Ayatollah Ruhollah Khomeini.

Regarding this revolution, we should mention that Khomeini and his supporters had a problem: they were not sure that they could trust the military forces that shortly before the end of the revolution and shortly before the establishment of the Republic, supported the dismissed leader.

Thus, this military force was set up and strengthened, representing a parallel to the regular one, which consisted of skilled fighters, great supporters of the new leadership and on which it was based entirely.

While the Iranian army has the role of defending the Iranian borders and maintaining the internal order, according to the Iranian constitution, IRGC aim to protect the political system of the Islamic Republic, as well as to prevent atypical or deviant internal movements, but also potential cou d'etats.

IRGC have approximately 125,000 military personnel and include ground forces, aerospace forces, naval forces and an intelligence services. Currently, its naval forces are extremely important, being responsible for the operational control of the Persian Gulf. Also, it controls the paramilitary militia called Basij, an entity with a rather strange military status.

IRGC are also responsible for the development of the Iranian ballistic missile system and as subordinate structures IRGC have a military faction known as the $\mathrm{Al}$ Quds Force, which conducts clandestine operations and other asymmetrical activities in the neighboring states, such as: Lebanon, Syria and Iraq.

Since its origin as an ideologically led militia, IRGC have played an important role in almost all stages of Iranian society's development. Having an extended social, political, military and economic role under President Mahmoud Ahmadinejad's administration - especially during the presidential elections from 2009 and the post-election suppression of the protest determined many western analysts to claim that its political power surpassed even the political power of the clerics, followers of the Sharia religion.

IRGC are considered as being a terrorist organization by the governments of Bahrain, Saudi Arabia and, of course, by the USA. Thus, in a public statement made on April 8, 2019, USA President Donald Trump stated about the IRGC that it would be a terrorist organization, which requires economic sanctions but also sanctions against members of this group and against affiliated individuals and groups.

The commander of the IRGC is, as of April 2019, Major-General Hossein Salami, who was preceded by Mohammad Ali Jafari (who led this military force from 2007 to 2019), who was preceded by Yahya Rahim Safavi, in 1997-2007.

IRGC are made up of several units of division level. Soleimani, the general killed by USA troops, has led one of these groups for decades, respectively the Quds Force, responsible for operations abroad, especially in the Near East. The number of the troopa that make up the Quds Force is not exactly known, but according to some sources this "is estimated at about 5000 soldiers" (Abrahamian, 2008, pp. 175-176), according to others, "the number of soldiers of this force could reach up to 17-20 thousand members" (Jack Watling), and 
according to other sources, this number "is between 10 and 20 thousand members" (Quds Force).

IRGC also control the Basij militias, paramilitary troops with approximately 90000 members, mobilized to maintain the order and to suppress protests, as happened in November 2019, when hundreds of antigovernment protesters were killed and several thousand injured.

Basij, like other institutions in Iran, was formed as a volunteer force during the Iran-Iraq war, but in the meantime it has taken root and has become a feared force of the state.

Due to General Soleimani, the Quds Force has mobilized various Shiite militias in at least five states in the region, which is supposed to bring together up to 200 thousand fighters. These Iranian interposed fighters operate within the limits of the law in the respective states, being engaged in attacks and conflicts that should not exceed the threshold of initiating war between states.

Another branch of the IRGC is the naval forces, which are mainly composed of armed vessels patrolling the Strait of Hormuz, where $20 \%$ of global oil production passes. In 2019, in the Strait of Hormuz, there were several clashes between Iranian vessels and foreign oil vessels.

Given the structure of the Iranian state, it appears that the IRGC is stronger than the regular Iranian army, and relations with these autonomous troops are not always harmonious, existing many moments of tension between the two entities.

\section{The Actual Situation between the \\ Two States}

It is obvious that relations between USA and Iran are not and will not be the best, too soon, especially after the killing of Iranian General Soleimani.

We must remember that the relations between these two states have deteriorated greatly after the USA imposed more many sanctions on Iran following the September 14, 2019 blows, executed from Iranian territory on oil installations in Saudi Arabia, specifically in Abqaiq, and Khurais, provinces in the southern and eastern areas of this state. These attacks, most likely executed by Iranian troops, included cruise missiles but also armament-carrying drones aimed at hitting Arab oil installations, which inevitably led to a decline in Saudi oil production and implicitly affected the international trading market oil, with major negative effects on the world economic and financial level.

These attacks have been harshly criticized in international plan, USA being the most fervent protester. Thus, at that time, Donald Trump, the USA President, said he does not want to start a war with anyone, but in the event that such actions will continue, the USA does not exclude the initiation of military action against Iran.

Following the deployment of these attacks, which the international press considered a treacherous act, Mark Esper, USA Secretary of Defense, announced the deployment of troops and equipment in Saudi Arabia and the United Arab Emirates, precisely to support the air defense and to prevent the attack with missiles launched from countries situated in the Arabian Gulf.

Jonathan Hoffman, the spokesman of USA Department of Defense, said that the Trump administration was waiting for the confirmation of the Saudi government that those attacks were carried out by Iran, before engaging in any action. Hoffman acknowledged that the evidence indicated that Iran was responsible for those attacks.

Given these, it is obvious that both the USA and Iran will be extremely cautious in any move or maneuver undertaken by the other state that may have an impact on areas of interest or influence. Surely Iran's majors representatives will prepare a series of asymmetrical operations against USA, from cyber-attacks to threats or attacks on USA personnel and USA 
allied personnel, that there is in various missions in the areas of influence. Also, it is obvious that USA will not give back to prepare to answer, as such, to all these actions through much firmer and more targeted actions.

\section{Iranian Answer - a Strategy Based on Three Pylons?}

Most analysts and experts in defense domain do not believe that Iran will risk an opened war with the USA to revenge the death of General Soleimani. Also, it is equally predictable that Iran will prepare and launch asymmetrical operations to attack Americans forces and interests, and also its allies in the Near East. In this category could be included the bombing executed by Iranian troops on two USA military bases situated in Iraq, immediately after the killing of the General Soeimani, who, fortunately, did not result in human casualties. Thus, we can firmly affirm that Iran will not back down to exploit all the conflicts in the area with an impact on the USA and its allies (from the smallest to the most significant conflicts), and here we could speak about Syria, but also to use other strategies for indirect attack on the USA or its allies.

In such a confrontation, but also considering the military technical possibilities, it is obvious that Tehran can be based on three pillars that we will list in the future.

The first pillar is represented by the actions carried out among foreign territories by the Quds troops, a kind of defense across borders. In this regard, the operations carried out by these troops are very well known, and it is obvious that these operations may affect USA forces situated outside Iran, but in the Middle East. This pillar is very sustainable due to the fact that the best fighters are part of these troops, but also they are the most trained, in different fields.

The second pillar of the Iranian answer to possible USA aggressions is the launching of Iranian missiles in order to strike further American targets. This is based on the important development of Iranian state technology in the area of missiles.

The third form of the Iranian state answer to USA and its allied attacks is particularly significant, being represented by the possibility of closure of the Strait of Hormuz and the prohibition of access of foreign ships. Adopting this measure, it could cause chaos in the global energy market, taking into account the uniqueness and the role of this strait, the access path for oil transportation to different parts of the world.

If Iran would have been restricted the access to the Hormuz Strait, this became a real conflict zone. In this case, Iran could become a very important player in the world economic market, as it is the state that represents the fourth largest oil reserve in the world (over 150 million barrels), which will make it to survive a significant period of time for such a blockage.

Most probably, Tehran does not expect to a ground invasion executed by USA and its allies because, as some political and military analysts declared that this effort is thus estimated: "1.6 million soldiers would be needed for a successful operation, which would not end in a lasting conflict with a counterinsurgency like the one in the Iraq conflict" (Iran will feel it must retaliate against US). Given the fact that the Iranian attack on some military bases in which there were, also, camped USA soldiers, on January 8 (as an answer to the killing of General Soleimani) did not kill anyone, and Donald Trump understood that he agrees and he is opened to easing tensions. Also, few political and military experts believe that Washington is considering a ground attack against Iran. 


\section{USA Troops Situation in the Region}

Several sources estimate that the number of USA soldiers in the Middle East would be around 70000. According to a source, a confirmation of the "distribution of American troops" in the Middle East, at 4th of January 2020 (Persian Force: How strong is Iran's army?), is the following:

- 14000 soldiers in Afghanistan (the largest contingent of USA soldiers in the area, given the unfinished conflict in this country, as well as NATO continues to deploy personnel for Resolute Support Mission, along with 8000 other soldiers from other NATO member countries);

- 13,000 soldiers in Qatar (there is a fairly close connection between the USA and this Gulf state, meaning both states work together to combat regional terrorism);

- 13,000 soldiers in Kuweit;

- 7,000 soldiers in Bahrain (most belonging to the Naval Forces, whose main mission is to maintain the security in the Persian Gulf, with troops stationed at the main naval support point in Bahrain, at the Shaykh Isa Air Base and at Khalifa Ibn Salman Port);

- 6,000 soldiers in Irak (they are presented in this state in order to carry out actions to support counter-terrorist activities carried out by ISIS troops. The number is most likely to have changed, as Iraqi officials said that USA troops are no longer welcome to remain in this country, the main reason being the killing of Iranian General Soleimani by USA troops);

- 5,000 soldiers in the United Arab Emirates (the small nation situated near the Hormuz Strait hosts a quite large number of USA soldiers, so that the USA can have a clearer picture of activities deployed in the Hormuz Strait. The troops are camped at Air Base from Al Dhafra, in Jebel Ali Port but also within Fujairah Naval Base);

- 3,000 soldiers in Saudi Arabia;

- and the list could continue to the smallest contingent that consisting of 600
American soldiers, that is located in Oman (having the mission tu sustain the operations against ISIS troops, but also to promote the regional stability).

In conclusion, we affirm that, in the current context, the best option for Iran is to maintain the status quo.

Also, we appreciate that neither of the two states in question really wants a confrontation, the relations between them being, rather, at a semi-formal level.

It is obvious that Iran does not want an opened conflict with the USA, and, more than likely, it will avoid a direct confrontation with the American adversary, but it is very likely that it will try to compensate the lower military power by supporting and conducting atypical operations, through proxy conflicts, carried out through interposed.

If we were to study the history of relations between the two states, we are able to ascertain that the assassination of Iranian General Soleimani by the USA and the immediate response of the Iranian troops materialized in the attack on USA bases in Iraq are, in fact, the first opened confrontations between the two countries after more than 40 years, more precisely after the 1979 year, when several Iranian protesters invaded the USA Embassy in Tehran, taking more American people as prisoners who were later released, after USA representatives made more diplomatic, military, and non-political efforts.

At this point, one of the questions we should reflect is the following: What would be the scenario that could take place as a result of all actions of the two actors we talked about: the outbreak of a regional war, the emergence of some terrorism acts or of some atypical warfare actions or a global economic crisis?

The discussion about the outbreak of a war between the two states shows us that Iran occupies a lower position compared to the USA, which has the strongest army in the world, as it is explained earlier in this article. 
But, the calmness situation between the two states is far from ending here, because the tensions from the past, as well as the existing ones, strongly mark the relations between them. The Iranians have not yet managed to revenge the killing of General Soleimani, the Iranian religious leader himself, the great ayatollah Ali Khamenei, being severely affected by the great american coup.

Some voices say that the Iranian religious leader, Khamenei, wait and wait, wanting to catch a favorable moment to start a confrontation that could have some favorable results for the Iranian state. On the other hand, USA President, Donald Trump has shown that he is not willing to let things to evolve in a negative way, obviously.

Moreover, the history (even the recent one) proves us that any place on this planet can be a target that could be attacked, whether this place is situated in South America, Africa, Europe, Asia or even in the USA. The General Soleimani has built networks both in the Mediterranean Sea and in the Gulf area, regions where there are enough american bases that could become real targets for the Iranian army or for its allies. There are already indications in Iraq that an important militia leader threats retaliation and his statements are made in the support of others threats made by supporters of the Tehran regime.

However, in the context in which a conflict between the two states would escalate, it is obvious that the attacks of Iranian militias would certainly intensify and entire this context would lead to numerous other terrorist attacks commited against freedom and democracy. Cyber attacks would also spread extremely quickly, as it was exemplified during this article.

The experience of the past years shows us that things can evolve more than that. An economic crisis can result relatively easily as a consequence of existing dissensions between states, especially when some of them or one of them represents significant economic powers. For example, the attacks on Saudi Arabia's oil extraction resources in 2019, attacks claimed by Shiite Houthi militias (attributed to Iran), had a global significant impact, in the sense that these attacks led to the rising of oil prices due to the substantial loss of capacity production of Saudi Arabia. Therefore, dissensions or misunderstandings between different countries of the world can cause serious problems at the global level, with a major economic impact.

However, the option of the two major states, the USA and Iran, to opt for diplomacy is a valid one. In the context in which the great European powers want to enter the Iranian market, and the Asians depend quite a lot on the oil from the Persian Gulf, the outbreak of a war in this area is undesirable. The Americans are also well aware that Iran has the military technology necessary to hit American bases situated inside the territories of the USA allied countries from this region, and they probably do not want a major conflict in this area.

A conciliatory position adopted by Iran is quite likely and, at the same time, represent the right and correct option for both sides. The political and social destabilization caused by USA sanctions is particularly significant for Iran, an eloquent example being the protests launched in November 2019. At the same time, the message sent by President Trump by killing General Soleimani was that the USA defends its interests, just resorting to force, and attacks and pressure on Washington are not agreed and will not be tolerated as they have been tolerated in the past.

At this point, however, we appreciate that neither of the two states in question really wants a confrontation, the relations between them being rather semi-formal.

It is obvious that for Iran, an open and direct conflict with the USA would be extremely costly and, more than likely, Iran 
will avoid a direct confrontation with the American opponent, but it is very likely that it will try to compensate the lower military power by supporting and deploying atypical operations, through proxy conflicts, carried out through intermediaries or interposed elements.

Although, for the moment, the spirits between the two nations seem to have calmed down, the risk of transforming the relations between these two states into a real war still persists. But, at the moment, it is obvious that the confrontation between these two states is chatacterized by tense but controlled relations, and concrete war actions are not revealed.

\section{REFERENCES}

Abrahamian, E. (2008). History of modern Iran. USA: Columbia University Press.

Danilo Ilić - the biography, available at: https://en.wikipedia.org/wiki/ Danilo Ili\%C4\%87, accessed on 19 February 2020.

Iran will feel it must retaliate against US, available at: https:// www.theguardian.com/ world/2020/jan/05/iran-will-feel-it-must-retaliate-against-us-say-military-analysts, accessed on 23 February 2020.

Iran's military response may be 'Concluded' but cyberwarfare threat grows, available at: https://www.nytimes.com/2020/01/08/us/politics/iran-attack-cyber.html, accessed on 23 February 2020.

Jack Watling, available at: https://foreignpolicy.com/channel/analysis/, accessed on 22 February 2020.

Kilo-class submarine, available at: https://en.wikipedia.org/wiki/Kilo-class submarine, accessed on 22 February 2020.

Middle East Military Strength. (2020). available at: https://www.globalfirepower.com/ countries-listing-middle-east.asp, accessed on 16 February 2020.

Persian Force: How strong is Iran's army?, available at: https://romania. europalibera.org/a/for $\% \mathrm{C} 8 \% 9 \mathrm{Ba}$-persan $\% \mathrm{C} 4 \% 83$-c $\% \mathrm{C} 3 \% \mathrm{~A} 2 \mathrm{t}$-de-puternic $\% \mathrm{C} 4 \% 83$-estearmata-iranului-/30370616.html, accessed on 23 February 2020.

Quds Force, available at: https://en.wikipedia.org/wiki/Quds_Force, accessed on 22 February 2020.

The attempt from Sarajevo, available at: https://ro.wikipedia.org/wiki/Atentatul de la Sarajevo, accesed on 10 February 2020.

Tian, N., Fleurant, A., Kuimova, A., Wezeman, P. D., \& Wezeman, S. T. (2018). Trends in world military expenditure. SIPRI Fact Sheet, available at: https://www.sipri.org/sites/ default/files/2019-04/fs_1904_milex_2018_0.pdf, accessed on 09 February 2020. 